学会賞候補には10編, 奖励賞候補に 4 編の推薦があり, 日本体育学会学会賞選考委員会で審 議の結果,

学会賞には, 能勢修一 明治期学校体育の研究 一学校体操の確立過程一 不昧堂出版

奖励賞には，鈴木秀人「教育技術法則化運動」に見られる体育の授業づくりについての検討： 過去の体育授業論との関係性に関する検討を中心に 体育学研究 第40巻第 4 号 221頁 233頁

を推庶した．最終決定は理事会（平成 8 年 9 月 24 日）に打いて行われる.

4）以下の内規を作成した.

名誉会員の推薦に関する内規

会則第 5 条に規定されている名誉会員には, 年齢75歳以上, 会員暦30年以上で学会に対して 貢献のあった会員，あるいは非会員で特別に貢献のあった者を推薦する.

顧問の推薦に関する内規

会則第31条に規定されている顧問について，権利・義務や推薦手順を規定した内規を作成し た.

5）文部省学術情報センターと覚え書きを交わし，「体育学研究」の登録を開始した．正式運用は 平成 9 年度からである.

\title{
2. 編集委員会報告
}

「体育学研究」第40巻（全 6 号）では，原著論文 19 編，資料論文 3 編の他に，第46回大会のキ一 ノートレクチャー 6 篇を揭載した. 第 41 巻第 1 号からは英文の寄稿案内の揭載, 編集後記の復活 など若干の手直しを行い，現在第 3 号が印刷中，第 4,5 号が編集中である.なお，目下編集委員 会では, 審査の公正さの確保, 論文の迅速な刊行, 掲載論文数の増大などを目指して, 審査抢よび 編集の在り方について抜本的な検討を行っている.

\section{3. 涉外委員会報告}

本学会の国際交流を促進するための基本方策について検討し，以下の結論を得た.

1）国際交流による本学会の活性化を図るために，理事会に国際交流専門委員会を設置する.

2）ICSSPE, ICHPER/SD, FIEP の 3 団体への加盟及び担当者の派遣は, 本学会が日本を代表す る学術組織としてのものとし, 積極的な参加を促進する.

3）アジア諎国との交流を促進するために，アジア担当委員を配置し，交流事業を行う。こうし た基本方針について理事会の承認が得られれば，規程改正を含む具体的な方策を提案する.

\section{4. 企画委員会報告}

巨大化した学会大会について，今後は領域横断的に大会を運営することによってスリム化をはか ることを検討中である.

\section{5. 学会大会委員会報告}

1）第47回学会大会は, 千葉支部が主管となり, 平成 8 年 9 月 25 日〜27日に千葉市で開催の予定 で準備を進めた。

2）第47回大会において一般研究発表論文について審查を行ったのは, 体育原理, 運動生理学, バイオメカニクス, 体育経営管理, 測定評価, スポーツ人類学の 6 専門分科会であった. 審査 委員会において慎重審査の結果, すべての論文が採用された.

3）日本体育学会第 48 回大会は, 平成 9 年10月 7 日 9 日の 3 日間, 新潟支部の主管で行われる 予定である。 


\section{6. 体育・スポーツ関連学会協力構想検討特別委員会報告}

1995年10月 3 日に第 1 回の委員会を開催し, 関連学会の代表者を集めて意見を聴取することが 了承された。同日開催の理事会においてこのことを報告し, 会議費の支出が了承された. 1996年 1 月学会事務局より「体育・スポーツ関連学協会意見交換会」を開催すれば参加するかどうかの問 い合わせの手紙を発送し, 21団体から回答があった.この件について, 引き続き検討中である.

\section{7. 日本体育学会組織運営将来構想検討特別委員会報告}

本委員会は平成 7 年 4 月に設置され, 学会を活性化するための組織運営体制改善の方策を検討

してきた．第46回総会においては，

1） 7,000人を数える会員の多様なニーズへの応対

2）研究活動の振興, とくに若い研究者への研究助成

3）研究成果の発表機会の充実

4）国際的（特にアジア地域に括ける研究とその交流発展への）貢献の推進

5）社会的期待への対応の充実

6）公的組織としての社会的地位の確立

等を実現するため, 組織・運営体制の改革と財政的基盤の整備強化が必要であり，その方策の一つ としての「学会の公益法人化」をふくめて検討することを報告, 了承された. その後, 他学会の状 況等を参考にして検討を重ねてきたが，今後は「体育学研究」等を通じて，全会員に問題点とそれ に関連する情報を提示し, 評議員を中心とした各支部・分科会における論議の積み重ねを求めるこ ととした.

\section{8. 学校体育問題検討特別委員会報告}

本委員会は, 調查協力委員の協力を得て,「次期教育課程に関する要望」と題する本文 2 ペー シ，国内・国外資料48ペーシの要望書を作成し，中央教育審議会会長有馬朗人氏に提出した．な お, 当委員会は今後の教育課程審議会等の審議の進行に対応して, 平成 9 年度も継続的に活動す ることが必要であると考えている.

\section{9. 日本学術会議関係}

1）体育学研究連絡委員会の名称が「体育学・スポーツ科学研究連絡委員会」に変更になった.

2) 平成 8 年度の体育学・スポーツ科学研究連絡委員会と体力科学研究連絡委員会主催の公開シ ンポジウムは，10月19日(土) $9: 30 \sim 16: 00 に$, 日本光電工業株式会社ホールにおいて開催さ れる予定である.テーマは「科学技術の発達と身体運動」であり，第 1 部は「スポーツ実践者 への科学技術の貢献」, 第 2 部は「コンピュータ処理技術がすすめるヒトのからだの理解」であ る. 